\title{
Experimentation of the KSIL Menthod (Konsep, Simulasi, Implementasi, Evaluasi) In Teaching Visiting Procedures to Students
}

\author{
Astrid Wangsagirindra Pudjastawa \\ SMK Negeri 3 Malang \\ Email: a.w.pudjastawa@gmail.com
}

\begin{abstract}
Abstrack
This study aims to determine whether the KSIL (Concept, Simulation, Implementation, and Evaluation) method offered can provide a better insight into visiting ethics compared to groups of students who are taught using conventional learning models in Javanese, Javanese in class XII SMK Negeri 3 Malang Semester I of 2019/2020 Academic Year. This type of research is quasiexperimental research. The population in this study were all class XII students of the Computer and Network Engineering Department at SMKN 3 Malang. The research sample was 28 students of class XII and 27 students of class XII ${ }^{b}$. The data obtained were analyzed using descriptive statistical analysis techniques and inferential statistics (t-test). The results of this study are: (1) Good visiting ethics insight of the experimental group students is very high with an average of 34.78 , (2) Good visiting ethics insight in the control group students is high with an average of 28.93. (3) There is a significant difference in the value of good visiting ethics insight between groups of students taught using the KSIL (Concept, Simulation, Implementation, and Evaluation) method and groups of students taught using conventional learning. The Javanese learning model for class XII students of SMK Negeri 3 Malang. Semester I of the 2019/2020 Academic Year. This shows that the KSIL learning method (Concept, Simulation, Implementation, and Evaluation) has a positive effect on students' insights about good visiting ethics.
\end{abstract}

Keywords: Visiting procedures, KSIL method, Javanese Speech Level

\begin{abstract}
Penelitian ini bertujuan untuk mengetahui apakah metode KSIL (Konsep, Simulasi, Implementasi, dan Evaluasi) yang ditawarkan dapat memberikan wawasan etika bertamu yang lebih baik daripada kelompok siswa yang dibelajarkan dengan model pembelajaran konvensional pada mata pelajaran Bahasa Jawa materi Unggahunggah Bahasa Jawa kelas XII SMK Negeri 3 Malang Semester I Tahun Pelajaran 2019/2020. Jenis penelitian ini adalah penelitian eksperimen semu. Populasi penelitian ini adalah seluruh siswa kelas XII jurusan Teknik Komputer dan Jaringan di SMKN 3 Malang. Sampel penelitian ini yaitu siswa kelas XII ${ }^{\mathrm{a}}$ yang berjumlah 28 siswa dan kelas XII $^{\text {b }}$ yang berjumlah 27 siswa. Data yang diperoleh dianalisis dengan menggunakan teknik analisis statistik deskriptif dan statistik inferensial (uji-t). Hasil penelitian ini yaitu: (1) Wawasan etika bertamu yang baik siswa kelompok eksperimen tergolong sangat tinggi dengan rata-rata 34,78, (2) Wawasan etika bertamu yang baik siswa kelompok kontrol tergolong tinggi dengan rata-rata 28.93. (3) Terdapat perbedaan yang signifikan nilai wawasan etika bertamu yang baik kelompok siswa yang dibelajarkan dengan metode KSIL (Konsep, Simulasi, Implementasi, dan Evaluasi) dan kelompok siswa yang dibelajarkan dengan model pembelajaran konvensional pada mata pelajaran Bahasa Jawa kelas XII SMK Negeri 3 Malang Semester I Tahun Pelajaran 2019/2020. Hal
\end{abstract}


ini menunjukkan bahwa metode pembelajaran KSIL (Konsep, Simulasi, Implementasi, dan Evaluasi) berpengaruh positif terhadap wawasan siswa tentang etika bertamu yang baik.

Kata Kunci: Metode KSIL, Unggah-ungguh Bahasa Jawa, Tata cara bertamu

\section{Introduction}

The main activity in the educational process is teaching and learning activities. The existing teaching and learning process is a determinant of the success of achieving educational goals. Students who learn are expected to experience changes both in the fields of knowledge, understanding, skills, values, and attitudes. According to (Waluyo, 2007) character education in children must be accustomed to behaving well; So that if a child doesn't do these good habits, he will feel guilty. Thus, good habits have become a kind of instinct, which will automatically make children feel uncomfortable if they don't practice these good habits.

The teacher as a figure who must be a role model for their students. The teacher in the big Indonesian dictionary is defined as a person whose job (livelihood or profession) teaches. However, the current demand is that teachers are expected to not only teach, but also be able to design learning activities. Learning means students acquire knowledge not only from the teacher as a teacher but also through learning resources (Anik Astari, I Wayan Sudiana, 2013).

Javanese language and literature as subjects have different characteristics from other subjects, for example, Mathematics, PPKN, and so on. In principle, Javanese language and literature are social facts as a means of communication. In other words, on the one hand, the Javanese language is a means of communication, and Javanese literature is a cultural product that uses language as its creative tool, while on the other hand Javanese language and literature must be taught to students through certain approaches. following its essence and function. The language learning approach focuses more on the performance aspects of language performance and language functions, so the right approach to use is the communicative approach. While the literature learning approach focuses more on literary appreciation, so the appropriate approach to use is the appreciative approach (Sukadaryanto, 2013).

Language learning is aimed at students' skills in using language that is appropriate to the context or pragmatic. Therefore, pragmatic communicative language is more of a form of performance than a knowledge system. This view has the consequence that language learning should place more emphasis on the function of language as a means of communication rather than learning about linguistics or science.

Concerning the teaching and learning process, referring to (Agustien, 2004) the Javanese language learning system needs to pay attention to the cultural context and the context of the local dialect language situation. The cultural context will give birth to various genres or types of text. Every text always appears in the context of a situation. The situation context has three elements, 
CIVICS EDUCATION AND SOCIAL SCIENSE JOURNAL (CESSJ)

Volume 3 Nomor 2 Edisi Bulan Desember 2021

namely field, tenor, and mode (Hasan \& Halliday, 1985). Field refers to what happened or what was said in the text. Tenor refers to the interpersonal relationship between the parties involved. Mode refers to the communication line used, namely spoken or written.

One way to adapt Javanese language learning by taking into account the cultural context and the local dialect language situation context is through the visiting method. Visiting is visiting other people's homes to strengthen bonds. What is meant by other people here can be neighbors, relatives (siblings), friends, and so on. Visiting, of course, has purposes and objectives, including visiting the sick, chatting regularly, chatting on business, chatting with families, and so on. Strengthening ties with neighbors, relatives, and friends is an Islamic religious order to always foster a sense of love, live in harmony, help each other and among humans (Chairilsyah, 2016).

Gathering will not only connect brotherly ties, but will also add a lot of insight or experience. Gathering can also teach and familiarize oneself with respectful character and courtesy. Children who respect their parents and others will always behave and behave following the norms prevailing in society.

Based on the description above, it is necessary to have a learning model and design that is following the diversity of students so that students can teach Javanese uploaded language material according to the cultural context and the context of the regional dialect language. situations that include planning, processing, and evaluation. Learning models and designs that can be used are learning models based on a combination of the following activities; (1) authentic learning, namely learning that allows students to learn in a meaningful context so that it can strengthen thinking and skills about important issues in life in society; (2) inquiry-based learning, which is interpreting learning strategies with scientific methods, to obtain meaningful learning; (3) problem-based learning, namely a learning approach that uses problems in the real world or surroundings as a context for students to learn critical thinking and problem-solving skills, as well as obtaining the main concepts of a subject; (4) service learning, which is a learning method that combines community service with school structures to reflect service, by emphasizing the relationship between services experienced and academic learning in schools; (5) work-based learning, namely a learning approach that uses a workplace context, and discusses the application of the subject context in the (Swara Ditpertais Cyber Media, 2004). The principles of learning activities above basically emphasize the application of concepts to subjects in the field, and use field problems to be discussed at school. The learning process takes place naturally so that the class is more lively and meaningful because students experience what they are learning (Nurhadi, 2004).

In line with these problems, one of the learning models that can be offered is the KSIL learning model (Concept, Simulation, Implementation, and Evaluation). This learning method is a method of developing roleplaying learning methods. Joyce \& Weil's role playing model method (Djamarah, 1996) defines a learning model as a "conceptual framework used as a guide in learning". Thus, the learning model is a conceptual framework that describes a systematic procedure for organizing learning experiences to achieve learning goals. Furthermore, role 
playing means "playing a role in the dramatization of social / psychological problems" (Gulo, 2005). So it can be interpreted that the role playing learning model is a way of presenting learning material by demonstrating, demonstrating, or demonstrating how to behave in social relationships. (Ruminanti, 2007) states that the role playing learning model has benefits, namely: (1) as a means of exploring students' feelings, (2) developing student skills in problem solving, (3) gaining inspiration and understanding that can influence attitudes. , values, and perceptions, (4) exploring the content of the subjects being studied, (5) preparing to enter society in the future so that students can bring themselves to the place, take care of themselves so that they are familiar if there are many different students in social life different.

Based on the advantages of the role playing learning model, many believe that the role playing learning model is suitable for learning because according to (Shaftel \& Shaftel, 1967) what is discussed can create an atmosphere that leads to real life problems., then role playing can encourage students to express their feelings, and carry out a psychological process that involves attitudes, values, and beliefs. To maximize the potential of roleplaying learning, the researcher then provides additional application of the roleplaying method. The implementation that the researcher means here is that students after doing a role play simulation then practice it directly to get real experience. Example: Participants play a role in visiting the teacher's house, so that at the implementation stage students visit the teacher's house. Researchers assume that by developing role playing learning methods that are collaborated with experiences in the field will get more benefits than ordinary roleplaying methods.

Based on the description above, the formulation of the research problem is: is there a significant difference in the insight into good visiting ethics in students who are taught using the KSIL (Concept, Simulation, Implementation, and Evaluation) model with students taught using conventional learning models in class XII SMK students Negeri 3 Malang Semester I of 2019/2020 Academic Year.

In line with the formulation of the problem, the purpose of this study is to describe the significant differences in the insights of hospitality ethics taught by the KSIL learning model and students taught by conventional learning models in class XII students of SMK Negeri 3 Jawa. Malang Semester I Academic Year 2019/2020. The hope is that by finding the best method, the character building of students, especially the courtesy with visit approach, can be achieved.

\section{Literature Review}

\section{KSIL (Konsep, Simulasi, Implementasi, dan Evaluasi) Concept}

Mastery or understanding of concepts can be interpreted as the ability of students to understand the meaning of science scientifically, both in theory and in its application in everyday life. Soit can be concluded that students with a good level of conceptual understanding will be able to work on problems in any form with the same concept. Then routine exercises to work on several variations of situations against certain knowledge can make it easier to understand and 
CIVICS EDUCATION AND SOCIAL SCIENSE JOURNAL (CESSJ)

Volume 3 Nomor 2 Edisi Bulan Desember 2021

remember a concept. The concept itself according to (Suyono, 2011) the concept is "a group or group of facts/information that has a meaning".

\section{Simulation}

According (Depdiknas, 2005) simulation is a training method that demonstrates something imitatively that is similar to a real situation; simulation: the depiction of a system or process by demonstration using statistical models or actors. (Syaefudin, 2005) simulation is "a replication or visualization of the behavior of a system, for example, an education plan that runs within a certain period". So it can be said that simulation is a model that contains a set of variables that represent the main features of an actual living system. Simulations allow decisions that determine how key features can be modified in real-time. (Anitah, 2007) simulation method is "one of the learning methods that can be used in group learning". The learning process using the simulation method tends to be an object, not an actual object or activity, but an imitation of teaching activities.

According to the (Depdiknas, 2005), the simulation method requires the availability of "adequate materials and tools to carry out simulations". (Djamarah, 2006), "the teacher's readiness to direct students in carrying out simulations, meaning that the teacher understands exactly what students should do in the simulation, the teacher acts as a guide who gives boundaries and directions. what is simulated does not go out of the corridor of learning objectives. "Teachers have to make a clear plan. In planning, there must be goals and indicators that are expected from the PBM that occurs. Besides, student readiness must be supported to carry out simulations, meaning that before the simulation students already understand. This means that this simulation method must be combined with other methods such as the lecture method, its function is to create conducive simulation prerequisites.

\section{Implementation}

Etymologically, the definition of implementation according to Webster's Dictionary (Wahab, 2008) is: The concept of implementation comes from English, namely implementation In Webster's large dictionary, implementation means providing the means to implement (providing the means to do something) and give practical influence to (impact / have an impact on something) Implementation comes from English which means implementing which means doing something that has an impact. Implementation is an action taken by an individual or official, government or private group directed at goal creation. which has been stated in the policy decision (Wahab, 2008).

\section{Evaluation}

In the Koran there is a verse about evaluation in surah al Baqarah verse 18 which reads (anbiūn $\bar{\imath}$ iasmaih $\bar{a}$ ) where the word begins with the word 'allama $\overline{a d a m a}$ al asma kullaha (Allah taught these names to Adam). Then the next verse reads anbiūn $\bar{\imath}$ iasmäiha. The word describes the activity of testing and assessing what was taught to Adam As. In another verse it also says faltanzur nafsun ma qaddamat lighad (everyone must correct what has been done in the past). This verse globally contains a message so that people are diligent in evaluating and 
introspective of the various activities that have been carried out (ma qaddamat) (Subur, 2016).

Conducting evaluation and introspection are two very important things for everyone who wants to be good and get ahead. Because humans can never know the achievements they have achieved; whether he is progressing and good or not if there is no comparison with his previous achievements. Here it is also understood that evaluation and introspection are routine and ongoing. The more frequent evaluation and introspection are the better. Evaluation and introspection also serve to spur enthusiasm for future activities. With this understanding, evaluation and introspection are important.

\section{Research Method}

This study uses the subjects of class XII students of the TKJ Department in the odd semester of the 2019/2020 school year. The reason for choosing the subject is because students who are used as the basis for the researchers' initial observations have a uniform level of understanding of the Javanese language speech level concept. This research is Quasi-Experimental Design because it does not allow controlling all the things that affect students' insight into student visiting ethics. Researchers only limit the variable use of learning methods and insight into learning ethics as measured by the pre-test and post-test scores.

In general, experimental research is carried out by taking the following steps, namely, 1) conducting inductive studies that are closely related to the problem to be solved, 2) identifying and defining the problem, 3) conducting literature studies and some relevant sources, formulating research hypotheses, determining variables, and formulating operational definitions and definitions of terms, 4) Making research plans, 5) Carrying out experiments, 6) Collecting rough data and experimental processes, 7) Organizing and describing data with predetermined variables, 8) Analyzing data and conducting significance test with relevant statistical techniques to determine the stage of the significance of the results, 9) Interpret the results, formulate conclusions, discuss, and prepare reports (Sukardi, 2006).

This experimental research was conducted with the following condtitions:

1. Experimental manipulation only on independent variables.

2. There is no random selection of groups

3. Using the control group as a comparison

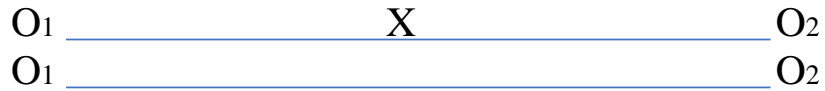

There are two groups to be observed, namely the treatment group and the control group. The selected class will be taught by the same teacher with the teaching method of upload-upload Javanese material in the speech level language according to the context and environment by visiting. One class of material is delivered using the KSIL cooperative learning method (Concept, Simulation, Implementation, and Evaluation) and the other class uses conventional methods (not treated). Lectures are conducted in 14 meetings (face to face), 1 pre-test, and 1 post-test. 
CIVICS EDUCATION AND SOCIAL SCIENSE JOURNAL (CESSJ)

Volume 3 Nomor 2 Edisi Bulan Desember 2021

The variable to be studied is student achievement as measured by the pretest and post-test scores for good insight into the material of hospitality ethics related to Javanese language subjects on the achievement indicator of being able to practice Javanese speech level following the context. . The visiting ethics insight variable was compared between the cooperative learning model KSIL type (experiment) and the conventional learning model (control). To achieve the research objectives, continuous data is needed which is then analyzed scientifically. In this study the data were collected using the test method with test questions instruments. The test was carried out twice, namely pre-test and posttest with the same questions.

\section{Result and Discussion}

Descriptive statistics to describe the mean, standard deviation of students' pre-test and post-test scores. Data normality test, variance equation test, and pretest and post-test mean difference test were conducted. Different tests are used to prove the existence of different insights about good visiting ethics in students who are taught by the KSIL cooperative learning method in learning Javanese subjects in Javanese language speech level material according to the context.

The learning process of Javanese Speech Level material is following the context through student visits using the KSIL method, the teacher divides students into groups of 4-5 students. Each student is then divided into several job disks, namely: interviewer ( 2 people), documentary ( 1 person), compiler of interview guidelines ( 1 person), and field director (1 person). For groups of 4 students, the interviewer can only be 1 person. Furthermore, the team members received guidance from the teacher at the drafting stage, namely about good visiting ethics and how to use Javanese Speech Level appropriately and well. In the prescription stage, the teacher approaches the language used by using $5 \mathrm{~W}+1 \mathrm{H}$ aids, for example in the Ngoko innocent variety the teacher explains using the $5 \mathrm{~W}+1 \mathrm{H}$ method with the help of the question What: what level of speech will be used? (Ngoko Lugu) Who: to whom can this speech level be used? When: when do we use this speech level? Why: why do we have to use this level of speech? Which: which words can be chosen and avoided when using that speech level and so on.

In the simulation stage, the teacher then performs role-playing utilizing cross grouping, where one group acts as a person who welcomes guests and the other group acts like a guest. Do not forget that the teacher also evaluates and mentors role-playing that has been done by students. The next stage is implementation, where students practice visiting someone to practice their learned knowledge of speech levels and visiting ethics. The implementation is carried out in 3 stages, namely 1) visiting friends' houses, 2) visiting teachers' houses, and 3) visiting village elders' houses. At the learning stage, each meeting repeats the evaluation stage of the concept-simulation implementation until it finishes visiting friends' houses, visiting teachers' houses, and visiting village elders' houses. The learning control group is relatively the same as learning in the experimental group. What distinguishes the two groups is how the material is studied. In the control group, learning was carried out conventionally in the form of transferring 
information from teachers to students through lectures and guided question and answer. table 1.

The ability of students before learning from the two groups can be seen in

Table 1. Students' abilities before lessons

\begin{tabular}{|c|c|c|}
\hline Source of variation & Experiment & Control \\
\hline$N$ & 28 & 27 \\
\hline Average & 64,6 & 64,1 \\
\hline Variance & 0,8327 & 0,5960 \\
\hline Standard deviation & 0,91 & 0,77 \\
\hline Maximum & 75 & 75 \\
\hline Minimum & 55 & 50 \\
\hline
\end{tabular}

Source: 2019 research data, processed

Student achievement after participating in the learning of the two groups can be seen in table 2 .

Table 2. Descriptive learning outcomes data after learning

\begin{tabular}{|c|c|c|}
\hline Source of variation & Experiment & Control \\
\hline$N$ & 28 & 27 \\
\hline Average & 81,3 & 75,9 \\
\hline Variance & 0,4537 & 0,7357 \\
\hline Standard deviation & 0,67 & 0,86 \\
\hline Maximum & 85 & 70 \\
\hline Minimum & 70 & 65 \\
\hline
\end{tabular}

Source: 2019 research data, processed

The results of the mean difference test in the pre-test data between the experimental and control groups can be seen in table 3 .

Table 3. Pre-test mean difference test

\begin{tabular}{|c|c|c|c|c|}
\hline Source of variation & Average & t count & t table & Criteria \\
\hline Experiment & 64,6 & & & \\
Control & 64,1 & 0,583 & 1,99 & No different \\
\hline
\end{tabular}

Source: 2019 research data, processed

The conclusion is that the experimental and control groups have relatively the same initial ability in understanding Javanese uploaded material according to the context and good visiting ethics in Javanese subjects. The results of the difference in the mean post-test between the experimental group and the control group can be seen in table 4 .

Table 4. Post-test mean difference test results

\begin{tabular}{|c|c|c|c|c|}
\hline $\begin{array}{c}\text { Source of } \\
\text { variation }\end{array}$ & Average & t count & t table & Criteria \\
\cline { 1 - 2 } Experiment & 81,3 & & & \\
\hline Control & 75,9 & 4,563 & 1,99 & Different \\
\hline
\end{tabular}


CIVICS EDUCATION AND SOCIAL SCIENSE JOURNAL (CESSJ)

Volume 3 Nomor 2 Edisi Bulan Desember 2021

Source: 2019 research data, processed

Based on the results of different tests, it can be concluded that learning with the KSIL cooperative method increases students' insight into the ethics of visiting students as indicated by the percentage value $\geq 80$ (grade A) which is $78.57 \%$ greater than the control. group $44.44 \%$. In the conditions before teaching, the initial ability (pretest value) between the experimental and control groups was relatively the same, namely the experimental group reached an average of 64.6 while the control group reached 64.1. The t-test results showed that there was no significant difference in the students' initial achievement of the two groups.

After learning in the experimental group using the KSIL method and the control group using the conventional method, it can be seen that the insight into the ethics of visiting the two groups shows a significant difference. This means that learning using the KSIL method can increase students' insights about the ethics of visiting students in the Java language upload-upload subject according to the context. This is because the KSIL method can condition students into a meaningful learning atmosphere. After all, students can actively cooperate and work together to collect information and improve communication skills to remind understanding of the subject matter being studied.

The results of this study were obtained from the results of research conducted by (Wafa, 2018) entitled Penggunaan Metode Role Playing Dalam Penigkatan Keterampilan Berbicara Bahasa Jawa Krama Pada Siswa Kelas V Sd who got the results that the use of the role playing method can improve student learning outcomes in cycle I $6857 \%, 78.93 \%$ second cycle, and 87.50\% second cycle. Research from (Puspita, 2018) entitled Pengaruh Model Pembelajran Inkuiri Berbasis Observasi Lapangan terhadap Kemampuan Berpikir Analitis which resulted that the scores obtained by the experimental class were higher in the control class. Through cooperative learning with the KSIL method, teachers can directly guide each individual who has learning difficulties. This is confirmed by (Slavin, 2010) which states that teachers spend at least half of their time teaching in small groups so that it will be easier to provide individual assistance. The atmosphere created from learning activities using the KSIL method is very interesting because it can direct students to be active in understanding the material being taught. This has an impact on the high mastery of the material studied by students and increased insight into good hospitality ethics that they have achieved. Unlike the control group, although there is an increase in insight into good hospitality ethics, the average learning achievement in this group is relatively lower than the treatment group because the conventional learning model has not been able to activate students optimally. Student activeness only appears when there is a discussion, practice questions or assignments. Low student motivation has an impact on lower results than the KSIL learning model.

\section{Conclusion}

Based on the results of the research and discussion, it can be concluded that there is a significant difference between students' knowledge of visiting ethics 
CIVICS EDUCATION AND SOCIAL SCIENSE JOURNAL (CESSJ)

Volume 3 Nomor 2 Edisi Bulan Desember 2021

in Javanese subjects and Javanese uploaded subjects following the context of KSIL cooperative learning. methods (Concept, Simulation, Implementation, Evaluation) and learning methods. conventional. The KSIL type cooperative learning method is proven to be more effective than the conventional learning method because it can direct students to actively innovate in understanding the material being taught, increase a sense of responsibility and increase learning achievement.

In connection with the above conclusions, it is suggested that the KSIL method that is being developed by researchers can be further explored. There is no best learning method, only learning that works under the situation and conditions at hand. The success of the KSIL method in class XII SMKN 3 Malang does not necessarily reflect the success of other schools.

\section{References}

Agustien, H. I. . (2004). Landasan Filosofis-Teoritis Pendidikan Bahasa Inggris. Jakarta: Depdiknas.

Anik Astari, I Wayan Sudiana, N. W. R. (2013). Pengaruh Model Pembelajaran Bermain Peran Lakon Wayang Kulit Terhadap Wawasan Nilai Karakter Siswa Pada Mata Pelajaran PKn Kelas V SD. Mimbar PGSD Undiksha, 1(1), 1-10.

Anitah, S. (2007). Strategi Pembelajaran di SD. Jakarta: Universitas Terbuka.

Chairilsyah, D. (2016). Mengajarkan Tata Cara Bertamu Kepada Anak Usia Dini (Untuk Guru dan Orang Tua).

Depdiknas. (2005). Kumpulan Metode Pembelajaran/Pendampingan. Jakarta: Balai Pustaka.

Djamarah, S. B. (1996). Strategi Belajar Mengajar. Jakarta: Rineka Cipta.

Djamarah, S. B. (2006). Strategi Belajar Mengajar. Jakarta: PT Rineka Cipta.

Gulo, W. (2005). Strategi Belajar Mengajar, Grasindo. Jakarta.

Hasan, R., \& Halliday, M. A. K. (1985). Language, context, and text: Aspects of language in a social-semiotic perspective. Victoria, Australia: Deakin University Press.

Nurhadi. (2004). Pembelajaran Kontekstual dan Penerapannya dalam KBK. UM Press.

Puspita, A. (2018). Pengaruh Model Pembelajaran Inkuiri Berbasis Observasi Lapangan terhadap Kemampuan Berpikir Analitis. Jurnal Pendidikan: Teori, Penelitian, Dan Pengembangan, 3(4), 468-474.

Ruminanti. (2007). Penggunaan Strategi Metode, dan Media Pembelajaran PKN SD Berbasis Belajar Aktif melalui Kegiatan Bermain Peran. Jurnal Sekolah Dasar, 16(1), 35-45.

Shaftel, F. R., \& Shaftel, G. (1967). Role-playing for social values: decisionmaking in the social studies. Englewood Cliffs, N.J.: Prentice-Hall.

Slavin, R. E. (2010). Cooperative Learning (Riset dan Praktik). Nusa Media.

Subur. (2016). Materi, Metode, dan Evaluasi Pembelajaran dalam Perspektif Al Qur'an. JPA, 17(1), 43-72.

Sukadaryanto. (2013). Pengembangan Desain Pembelajaran Bahasa Jawa Berbasis Kompetensi di SMA Se-Jawa Tengah. Lingua, IX(2), 62-70. 
CIVICS EDUCATION AND SOCIAL SCIENSE JOURNAL (CESSJ)

Volume 3 Nomor 2 Edisi Bulan Desember 2021

Sukardi. (2006). Penelitian Kualitatif-Naturalistik dalam Pendidikan. Jakarta: Usaha Keluarga.

Suyono, H. (2011). Belajar dan pembelajaran Teori dan konsep Dasar. Bandung: PT Remaja Rosdakarya.

Swara Ditpertais Cyber Media. (2004). Kurikulum Berbasis Kompetensi. Swara Ditpertais: No. 17 Th. II, 18 Oktober 2004. Retrieved from http://www.ditpertais.net/swara/warta17-03.asp

Syaefudin, S. U. (2005). Total Quality Manajement dalam Konteks Pendidikan. Bandung: Prodi Adpen UPI.

Wafa, H. (2018). Penggunkan Metode Role Playing Dalam Peningkatan Keterampilan Berbicara Bahasa Jawa Krama Pada Siswa Kelas V SD. Kalam Cendekia PGSD Kebumen, 6(4).

Wahab, S. A. (2008). Analisis Kebijaksanaan dari Formulasi ke Implementasi Kebijaksanaan Negara. Jakarta: PT Bumi Aksara.

Waluyo, E. (2007). Pendidikan Moral dan Budi Pekerti dalam Perspektif Perubahan: Menggagas Platform Pendidikan Budi Pekerti Secara Kontekstual dan Futuristik. Jakarta: Bumi Aksara. 